\title{
STRENGTHENING THE POSITION OF ATTORNEY IN THE 1945 CONSTITUTION OF THE REPUBLIC OF INDONESIA
}

\author{
By :
}

Muhammad Juriko Wibisono, Amancik, Ardilafiza

\begin{abstract}
The arrangement of the Attorney institution of the Republic of Indonesia in the 1945 Constitution is less clear and less detailed about its position as well as its authority in law enforcement. Departing from the description of the weakness of the Attorney of the Republic of Indonesia's position above, it is necessary to place the Attorney of the Republic of Indonesia proportionally in order to be autonomous and independent in the perspective of the rule of law theory and the power sharing theory. Based on the results of the study, it can be concluded that the position of Attorney in the 1945 Constitution which was attached in the executive domain had caused a lot of debate. The debate was focused on whether it was a right choice to practically put the Attorney as a law enforcement institution in Executive domain where it should had been legally put in judiciary domain. Furthermore, strengthening the position of Attorney in the 1945 Constitution can be done though the fifth amendment of the 1945 Constitution, therefore the adjustment of the Attorney position must be explicitly stated in the institutions within the environment of judicial power accompanied by its authority.
\end{abstract}

Keywords: Attorney, 1945 Constitution, power sharing theory, judiciary, executive. 


\section{A. INTRODUCTION}

\section{Research Background}

Prosecutors in the Indonesian criminal justice system are organized in a state institution called the Attorney of the Republic of Indonesia. The Attorney of the Republic of Indonesia is led by the Attorney General. The Attorney General is a high-ranking legal official and acts as a guardsman of the public interest. ${ }^{1}$ In carrying out its functions, in the criminal justice system, the duties and functions of the prosecutor set out in Articles 14 and 15 of the Criminal Procedure Code. The Attorney, with a very dominant function as dominus litis principle holder, controls the case process that determines whether a person can be declared as a defendant and submitted to the Court based on legal evidence according to the law, and as executive ambtenaar executor of the determination and decision of the court in criminal cases. ${ }^{2}$

The Attorney is placed in executive power domain, while the

1 Jeremy Pope, Strategi Memberantas Korupsi, the Cooperation of Yayasan Obor and Indonesian International Transparency, 2003, p.137.

${ }^{2}$ Andi Hamzah, Hukum Acara Pidana Indonesia, Jakarta, Sinar Grafika, 1996, p.72. foundation of its formation lies in the chapter on judicial power. This must be read more comprehensively, meaning that the attorney's professionalism and independence in carrying out the prosecution task must be placed as something that should not be intervened at all. Meanwhile, constitutionally, the attorney is positioned under the authority of the government as the head of government. In such a position, a President has the authority to order the Attorney Office to pursue legal proceedings against a case. In fact, in Article 37 paragraph (1) of Law Number 16 of 2004 concerning the Attorney of the Republic of Indonesia as the attorney general is responsible for prosecution carried out independently for the sake of justice based on law and conscience.

The problematic problem was rooted in the regulation of the Republic of Indonesia Attorney's Office in the 1945 Constitution which was less clear and less detailed about its position as well as its authority in law enforcement. Another problem was not only on whether the Attorney of the Republic of Indonesia should be in executive or judiciary domain, 
but also whether the executive domain intervenes or not, as well as the integrity issue of the attorney office itself. As a result of the lack of clarity in the 1945 Constitution, there was a continued excess in the laws and regulations under the 1945 Constitution.

Departing from the description of the weakness of the Attorney of the Republic of Indonesia's position above, it is necessary to place the Attorney of the Republic of Indonesia proportionally in order to be autonomous and independent in the perspective of the rule of law theory and the power sharing theory. ${ }^{3}$

\section{Identification of Problems}

Based on the background of the problems that have been described, the formulations of the problem focused of this research were:

1. How was the position of the Attorney of the Republic of Indonesia in the 1945 Constitution of the Republic of Indonesia?

2. How to strengthen the position of the Attorney of the Republic of

\footnotetext{
${ }^{3}$ Marwan Effendy, Kejaksaan RI Posisi dan Fungsinya dari Perspektif Hukum, PT. Gramedia Pustaka, Jakarta, 2005, p 49-51.
}

Indonesia in the 1945 Constitution of the Republic of Indonesia?

\section{B. RESEARCH METHODS}

\section{a. Types of Research}

This type of research used in this study was normative legal research.

\section{b. Research Approach}

1. Statute approach

The statute approach used in this research was applied to examine, to understand, and to explore as well as to examine various laws and regulations governing the position of the Attorney of the Republic of Indonesia.

2. Conceptual approach The conceptual approach was used to interpret the 1945 Constitution regarding the position of the Attorney of the Republic of Indonesia.

3. Historical approach The historical approach was carried out to trace the position of the Attorney of the Republic of Indonesia in the 1945 Constitution and other laws relating to the position of the Attorney.

4. Comparison Approach 
This approach was carried out by comparing regulations from one country to another regarding the same thing.

\section{c. Legal Materials}

This research used secondary legal material, which is legal material obtained or collected by researcher from existing sources. The legal materials needed were as follows:

1. Primary Legal Materials Namely legal material that is authoritative means to have authority. Primary legal materials used by the author consist of legislation and legal products.

2. Secondary Legal Materials Secondary legal materials are closely related to primary legal materials.

3. Tertiary Legal Materials Tertiary legal materials are materials that provide instructions and explanations for primary and secondary legal materials in the form of lecture dictates, legal dictionaries, articles and legal websites relating to the Attorney General's Office. d. Legal Material Collection Procedure

The legal material collection procedure used in this research was the study of literature.

\section{e. Legal Material Processing}

The processing of legal materials was carried out based on primary, secondary and tertiary legal materials obtained both from library research and field research.

\section{f. Legal Material Analysis}

In the process of analyzing and interpreting the legal material collected, the writer used a qualitative juridical analysis method, namely by using nonstatistical analysis that starts from the norms, principles and regulations that exist as positive legal norms, which then qualitatively being analyzed according to its contents. Furthermore, the collected legal materials were interpreted, and then analyzed descriptively and qualitatively by using the deductive method.

\section{RESULTS AND DISCUSSION}

1. Position of the Attorney of the Republic of Indonesia in the 


\section{Constitution of the Republic of Indonesia}

The official who carries out the criminal prosecution in the Indonesian criminal law system is called the Prosecutor. ${ }^{4}$ The Republic of Indonesia Attorney's position in relation to its constitutionality basis is somewhat contradictory in its juridical philosophy, where the Indonesian Attorney is a Government institution based on Law Number 16 of 2004 concerning the Attorney of the Republic of Indonesia, but the basis for the arrangement is implicitly formulated in Article 24 paragraph (3) of the 1945 Constitution (the fourth amendment) regarding other bodies whose function is related to Judicial Power, where there is a conflict between the position of the Attorney placed in the executive power domain, while the basis for its establishment is in the chapter on judicial power, so that it greatly influences the implementation of law enforcement duties in the future particularly in strengthening its role in the power of prosecution and other authorities related to this matter regulated in the legislation under the

\footnotetext{
${ }^{4}$ Ibid, p.56.
}

1945 Constitution (vertical synchronization).

Yudi Kristiana explained that in Law Number 16 of 2004 concerning the Attorney, there were inconsistent provisions, including: ${ }^{5}$

1. Article 2 paragraph (1) which confirms that the Attorney exercises the authority of the State in the field of prosecution, but at the same time it is also declared as a government institution. Whereas state power in the field of prosecution is part of judicial power, which has consequences for independence, and should not be part of government (executive) power.

Relevant to the inconsistency regarding the provisions of Article 2 paragraph (1) which confirms that the Attorney exercises the power of the State in the field of prosecution, but at the same time is also declared as a government institution, can also be seen in the considerations considering letter $b$ of Law Number 16 of 2004 as follows:

5 Yudi Kristiana, Menuju Kejaksaan Progresif; Study tentang Penyelidikan, Penyidikan, dan Penuntutan Tindak Pidana Korupsi, Masyarakat Transparansi Indonesia, Jakarta, 2010, p.292. 
"that the Attorney of the Republic

of Indonesia is one of the bodies whose functions are related to judicial power according to the 1945 Constitution of the Republic of Indonesia".

Other inconsistencies that are still related to the provisions of Article 2 paragraph (1) can also be seen from the considerations to consider letter $\mathrm{c}$ of Law Number 16 Year 2004 as follows: "that in order to further strengthen the position and role of the Attorney of the Republic of Indonesia as a government agency implementing State power in the field of prosecution, it must be free from the influence of any party's authority".

2. Article 2 paragraph (2) the Prosecutor in exercising his authority is independent, however Article 8 paragraph (2) the prosecutor must be held hierarchically responsible, and Article 18 (1) states expressly that the attorney general is the highest controller, thus the independence of the prosecutor denied by hierarchical accountability.
It cannot be denied, that the long debate about the independence of the Attorney and its position in the constitutional structure in Indonesia is mostly due to the unclear position of the Attorney in the 1945 Constitution. In the 1945 Constitution, Attorney was only implicitly stated in Article 24 paragraph (3) of the 1945 Constitution which stated, "Other bodies whose functions are related to judicial power are regulated by law."6 The main concern that deserves attention is the need for a constitutional reposition of the Republic of Indonesia Attorney where there is the absence of a constitutional basis, the implementation of which is only based on limited functions and powers of the Law has actually led to stigmatizing highlights regarding the success of this institution. Legislation on the exercise of the authority and function of the Indonesian Attorney to fulfill the mandate must be based on legitimacy on a more acceptable constitutional basis. In carrying out the highest prosecution function, the Indonesian Attorney must be given

\footnotetext{
${ }^{6} \mathrm{RM}$, Surachman and Jan. S. Maringka, Eksistensi Kejaksaan Dalam Konstitusi di Berbagai Negara, Sinar Grafika, Jakarta, 2017, p. 100 .
} 
duties and authority that are independent from the highest executive power. As the highest prosecuting institution, the Attorney of the Republic of Indonesia is held accountable for implementing Article 4 of the MPR Decree Number XI/MPR/1998, November 13, 1998. The parameters were efforts to eradicate corruption, collusion and nepotism must be carried out firmly against anyone. With due regard to the lex superior principle of the order of the laws and regulations Article 7 paragraph (1) of Law Number 12 of 2011, it is appropriate that the Indonesian Attorney as the institution responsible in the highest prosecution field requires constitutional protection in order to maintain its integrity and independence. ${ }^{7}$

\section{Strengthening the Position of} the Attorney of the Republic of Indonesia in the 1945 Constitution of the Republic of

\section{Indonesia}

Based on the discussion in the formulation of the first problem, it can be stated that the position of the

${ }^{7}$ http://requisitoire-magazine.com/halihwal-reposisi-konstitusional-dan-independensikejaksaan/, accessed on the $21^{\text {st }}$ of November 2019. prosecutor's institution is considered unclear, not yet strong, even ambiguous and equalized with other State Civil Apparatuses and eliminate the special nature of the law enforcement function that has occurred nationally. Therefore, it is necessary to propose that the prosecutorial institution must be included as one of the agendas in the fifth amendment of the 1945 Constitution.

The importance of the existence of a prosecutor's office in the constitution because constitutionally the only statement that can be used as a basis for reference is only the provisions of Article 24 paragraph (3) of the 1945 Constitution of the Republic of Indonesia which ironically also does not explicitly mention the prosecutor's institution. The Attorney which should have been the main state organ has so far been placed only as an institution that is considered unimportant, does not need to be declared and given its place and position.

The reasons for the need to strengthen the position of the Attorney of the Republic of Indonesia 
in the 1945 Constitution of the Republic of Indonesia are as follows:

\section{a. Strengthening Philosophy of the} Attorney position of the Republic of Indonesia in the Constitution of the Republic of Indonesia of 1945

Law is needed to prepare and to maintain a nation to achieve its objectives in the state. The law direction is usually referred to as law politics, which can be found in the constitutions of each country. Justice as one of the missions of the ideal legal system turns out to be the core of the legal politics of regulating the main mission of the Republic of Indonesia. This can be seen from the formulation of the first paragraph of the Preamble of the 1945 Constitution:

"Whereas independence is a genuine right of all nations and any form of alien occupation should thus be erased from the earth as not in conformity with humanity and justice".

Also in the second paragraph of the Preamble of the 1945 Constitution:
".... Whereas the struggle of the Indonesian independence movement has reached the blissful point of leading the Indonesian people safely and well before the monumental gate of an independent Indonesian State which shall be free, united, sovereign, just and prosperous".

The mission of the legal state is as a guarantor of justice were it made explicit, although in the1945 Constitution before the amendment it also been stated in the explanation of the constitutional system of the Republic of Indonesia as a legal state (rechtsstaat), and not as a state based on the power alone (machstaat). Then it was translated the division of agency's role as a legislator (legislative) conducted by parliaments, law enforcement (executive) by governments and institutions the control of law enforcement (judicial), conducted by the institution which in the Constitution of 1945 called as the institution of judicial power.

Attitude and constitutional choice in maintaining law and justice seen from the Political Law of 
Judicial Power. From the name of the chosen judicial authority, it has already been shown that the institution which becomes the rule of law and justice rests on the judicial system, in essence, the judges. This institution must maintain a balance of power to protect citizens, both legislative and executive bodies.

The basis of judicial power is formulated in Article 24 of the 1945 Constitution of the Republic of Indonesia as follows:

(1) The judicial powers shall be independent with the authority to organize the judicature to uphold law and justice.

(2) The judicial powers shall be carried out by a Supreme Court and by its subordinate judicatory bodies dealing with the general, religious, military, state administrative judicial fields, and by a Constitutional Court.

(3) Other bodies dealing with judicial powers are to be regulated by law

The terminology of judicial power shows that the core of law enforcement and justice is based on the judiciary. In addition to judicial power politics, the constitution also enhances the legal rights of citizens.

\section{b. The Attorney Must Be Independent and Free of Conflicts of Interest, therefore} The It Has Not To Responsible to the President but to the People (The Public) Through The DPR

The President of the Republic of Indonesia holds governmental authority according to the Constitution (Article 4 paragraph (1) of the 1945 Constitution of the Republic of Indonesia, Chapter of The State's Executive Power). All state institutions which are not specifically mentioned in the Constitution, are politically lawful, the concerned state is part of the system of government (executive) of the state lead by the president. The Attorney is a government official whose duty is to assist the president in realizing the justice ordered by the Constitution.

Further confirmed that the Attorney did not make clumps of the judiciary but under the coordination of law enforcement executives. Attorneys confirmed as a public prosecutor since the 
enactment of Law No. 8 of 1981

on the Code of Criminal Procedure (Criminal Procedure Code).

Prosecutor besides representing the state and prosecute all violations of criminal law, it was also given the right to waive claims (opportunity), if there are reasons of place to protect the public interest.

In the position as part of the executive, the position same as the police. This principle according to Dio Ashar Wicaksana, as also confirmed in the Law No. 5 of 1991 of Constitution regarding the Attorney of the Republic of Indonesia, which mentions that the Attorney as "government institutions that implement state power in the prosecution in the order of arrangement of the power of law enforcement agencies and justice". From this consideration, there is an important change that contains an affirmation of the position of the attorney's position which was previously said to be a tool of the state but after the enactment law, it was turned into a government agency.
When referring to Article 24 paragraph (3) of the 1945 Constitution states that "Other bodies dealing with judicial powers are to be regulated by law", which is reinforced in Article 38 paragraph (1) of Law No. 48 of 2009. According to Dio, the meaning of "other bodies" including police, attorney, lawyers and penitentiary. ${ }^{8}$

Based on this condition, the position of the attorney as part of government would lead to a contradiction where in one hand they are part of the domain of the executive which under the President as the holder of the executive power, but on the other hand the attorney shall perform the functions, duties, and authority as an enforcement agency of law. With the contradiction between the position of the attorney to function, it is necessary to see also the provisions in Article 2 paragraph (2) of Law No. 16 of 2004 that the prosecution is implemented independently.

${ }^{8}$ Dio Ashar Wicaksana, " Kedudukan Kejaksaan RI Dalam Sistem Hukum Tata Negara Indonesia ", Fiat Justitia Vol.1/No.1/March 2013, p. 3 . 
President Sukarno once dismissed the general prosecutor, Soeprapto on the ${ }^{1 \text { st }}$ of April 1959 and Mr. Goenawan in 1962 for no apparent reason. The public suspects that the dismissal of the two general prosecutors was related to the investigation of ministers in the Dwikora Cabinet who were suspected of committing criminal acts of corruption. ${ }^{9}$ So also in the era of President of BJ Habibie, the general prosecutor A. Soedjono C. Atmonegoro only had served for three months as willing to investigate the former President, Soeharto. ${ }^{10}$

\section{c. The attorney is the Main part of} Judicial Power

The author agrees with Barda Nawawi Arief who states that Judicial Power is fitting to be reviewed because essentially the judicial power is the power of the state in enforcing the law. So the power of justice is identic with the power to enforce the law or the power of law enforcement. The nature of such understanding is revealed in the formulation of Article 1 of Law no. 14/1970

\footnotetext{
${ }^{9}$ Marwan Effendy, op.cit. hlm.7

${ }^{10}$ ibid
}

Juncto Law No. 35/1999 concerning Judicial Power, which is in the sentence which states: "To uphold law and justice based on Pancasila, for the sake of the implementation of the rule of law of the Republic of Indonesia". Only, unfortunately, that sentence was not formulated as the essence of the definition of judicial power but instead was formulated as the objective of holding a judiciary". Only, unfortunately, that sentence was not formulated as the essence of the definition of judicial power but instead was formulated as the objective of holding a judiciary. ${ }^{11}$

Based on this, the attorney as one of the law enforcement agencies other than the Police and Justice, can not be separated from the judicial authorities, by Andi Hamzah who stated that the Prosecutor should be within the scope of judicial power not in the power of government. ${ }^{12}$

\footnotetext{
${ }^{11}$ Barda Nawawi Arief, Masalah Penegakan Hukum dan Kebijakan Hukum Pidana dalam Penanggulangan Kejahatan, Kencana, Jakarta, 2007, p. 33-34.

${ }^{12}$ Andi Hamzah, "Posisi Kejaksaan dalam Sistem Ketatanegaraan Republik Indonesia ", paper presented at the Seminar at welcome Day of Hari Bakti Adhiyaksa, Jakarta, July 20th, 2000, p. 5-6.
} 


\section{d. Legal Comparison With Other Countries}

In the legal system of the United States, the Attorney institution has experienced changes that are influenced by local needs. An example is the appointment of the district attorney who is not appointed but elected by the people in a general election, therefore the local prosecutor has a good performance. Therefore, in general, the district attorney was elected to become political figures. $^{13}$

Based on this, even though the district attorney which is selected becomes political figures, but it has a positive impact because the election is done directly by the people, then the elected district attorney almost certainly was not the people whose performance is mediocre or prosecutor who often make decisions arbitrarily. District Attorney is not subordinate to the State Attorney General nor a subordinate of the Federal Attorney General. It can be said that the District Attorney is directly responsible to the people P. 36-37.

\footnotetext{
${ }^{13}$ Surachman and Jan S. Maringka, op.cit.,
}

and the people have the right to supervise the performance of the district attorney, therefore, the district attorney can be free of interference from any party to the make a decision.

The same thing is also regulated in the Constitution of Malaysia in paragraph (1) which states that the Yang di-Pertuan Agong, based on the advice of the Prime Minister, appoint a qualified person to be a judge of the Federal Court to be Attorney General of the Federal. ${ }^{14}$ Meanwhile, in Brunei, the arrangement of the Attorney General in the Constitution is set for 3 paragraphs. However, the Constitution of Brunei set firmly on Article 81 paragraph (2) that states in exercising this authority, the Attorney General is not subject to the command or control of any person or authority. ${ }^{15}$

\section{CLOSING}

\section{Conclusion}

1. In the provision of Article 24 paragraph (3) of the 1945 Constitution, the Attorney is only implicitly referred to as

\footnotetext{
${ }^{14}$ Ibid., P. 65.

${ }^{15}$ Ibid., P. 68.
} 
"Other bodies dealing with judicial powers are to be regulated by law". Based on this article, many parties have the opinion that attorney is one of the bodies whose functions are related to the judicial authority, therefore, many people assume that attorneys should be in the realm of the judiciary and attorneys position should be free from executive influence.

2. The strengthening of the authority of the Republic of Indonesia position in the 1945 Constitution of the Republic of Indonesia can be done through an amendment to the five Constitution of the Republic of Indonesia of 1945 , so that the regulation of the attorney's position is not only regulated in Article 24 paragraph (3) of 1945 Constitution of the Republic of Indonesia.

\section{Suggestion}

1. The Attorney of the Republic of Indonesia in the future is in accordance with the characteristics of the constitutional system, is expected to become a "state body", and explicitly stated in the 1945 Constitution separate from the Judiciary.

2. Recognizing that the power of prosecution is part of judicial authority, the understanding of judicial power set out in the 1945 constitutional amendments is very necessary to be reviewed. Authority in the field of criminal law enforcement is in fact in an integrated criminal law enforcement system.

\section{REFERENCES}

\section{A. Books}

Andi Hamzah, Hukum Acara Pidana

Indonesia, Jakarta, Sinar Grafika, 1996

Barda Nawawi Arief, Masalah Penegakan Hukum dan Kebijakan Hukum Pidana dalam Penanggulangan Kejahatan, Kencana, Jakarta, 2007

Jeremy Pope, Strategi Memberantas Korupsi, Kerjasama Yayasan obor dan Transparansi Internasional Indonesia, 2003

Kristiana, Menuju Kejaksaan Progresif studi tentang penyelidikan, penyidikan dan penuntutan tindak pidana korupsi, Masyarakat Transparansi Indonesia, Jakarta, 2010.

Marwan Effendy, Kejaksaan RI Posisi dan Fungsinya Dari Persepektif Hukum, PT. Gramedia Pustaka, Jakarta, 2005 
RM, Surachman dan Jan. S. Maringka, Eksistensi Kejaksaan Dalam Konstitusi di Brbagai Negara, Sinar Grafika, Jakarta, 2017

\section{B. ETC}

http://requisitoire-magazine.com/halihwal-reposisi-konstitusional-danindependensi-kejaksaan/, diakses pada tanggal 21 November 2019
Andi Hamzah, "Posisi Kejaksaan dalam Sistem Ketatanegaraan Republik Indonesia", Makalah disampaikan pada Seminar menyambut Hari Bakti Adhiyaksa, Jakarta 20 Juli 2000

Dio Ashar Wicaksana, "Kedudukan Kejaksaan RI Dalam Sistem Hukum Tata Negara Indonesia", Fiat Justitia Vol. 1/ No. 1/Maret 2013 